\title{
İstanbul ve çevirmenleri: Ahmet Hamdi Tanpınar ve Orhan Pamuk’un edebi anlatılarında şehrin çevirisi
}

\section{Şule DEMİRKOL ERTÜRK1}

\begin{abstract}
APA: Demirkol Ertürk, Ş. (2020). İstanbul ve çevirmenleri: Ahmet Hamdi Tanpınar ve Orhan Pamuk'un edebi anlatılarında şehrin çevirisi. RumeliDE Dil ve Edebiyat Araştırmaları Dergisi, (19), 876-886. DOI: 10.29000/rumelide.752909.
\end{abstract}

$\ddot{\mathbf{O} z}$

Şehrin bir "söylem” olarak çözümlenebileceği ve "kültürel bir metin” olarak okunabileceği görüşünden yola çıkan bu makale, edebi yapıtlarında İstanbul’u özel bir konuma yerleştirmiş olan Ahmet Hamdi Tanpınar ve Orhan Pamuk'u, şehrin birer çevirmeni olarak ele almaktadır. Sunulan vaka çalışmalarında, Tanpınar'ın “İstanbul” başlıklı denemesi ve Pamuk'un İstanbul, Hatıralar ve Şehir başlıklı kitabı, şehrin çevirileri olarak incelenmektedir. Bu çerçevede Tanpınar ve Pamuk, bir metin olarak ele alınan şehri, farklı yorumlarla okuyan ve kendi "bilişsel durumları" ve "tavırları" doğrultusunda yeni bir dile aktaran çevirmenler olarak görülmektedir. Tıpkı diller arası çeviride olduğu gibi, bu çeviride de kaynak metnin yani şehrin tüm özellikleriyle erek metne aktarılması mümkün olmayacağı için bir seçme ve eleme sürecinin söz konusu olduğu ileri sürülmektedir. Maria Tymoczko'nun da belirtmiş olduğu gibi, herhangi bir kaynak dilde yazılmış bir metindeki tüm bilgi ve anlamın çeviride aktarılması mümkün olmadığı için çevirmenler kaynak metnin bazı yönlerini öne çıkarırken bazılarını dışarıda bırakarak kaynak metnin kısmi ve taraflı temsillerini oluştururlar; ancak bu kısmi temsiller, metonimi yoluyla tüm metni temsil eder. Bu makale kapsamında incelenen iki şehir anlatısında da benzer bir seçme ve eleme sürecinin söz konusu olduğu, şehrin çevirmeni olarak görülebilecek iki yazarın anlatılarında şehrin farklı yönleriyle öne çıtı̆̆ı ve bu anlatıların metonimik olarak tüm şehrin yerine geçerek şehrin anlaşılması için sembolik bir düzen kurduğu iddia edilmektedir.

Anahtar kelimeler: Çeviribilim, edebiyat çevirisi, Ahmet Hamdi Tanpınar, Orhan Pamuk, Türk edebiyatında İstanbul

\section{Istanbul and its translators: Translation of the city in Ahmet Hamdi Tanpınar's and Orhan Pamuk's literary narratives}

\begin{abstract}
Based on the assumption that cities can be analysed as "discourse" and read as "cultural text", this article proposes to approach Ahmet Hamdi Tanpınar and Orhan Pamuk, who placed a special value on the city of Istanbul, as translators of the city. The two case studies devoted respectively to Tanpınar's essay titled “İstanbul" and Pamuk's book titled İstanbul, Hatıralar ve Şehir, examine the selected narratives as translations of Istanbul. From the same perspective, Tanpınar and Pamuk are considered as translators of Istanbul, who read the city as a source text, bringing their own interpretation to it, and rendering the city text into a new language, in line with their "cognitive states" and "attitudes". It is argued that translators of the city have to make choices, transferring some aspects of the city into the target text while excluding some others, just like in interlingual

1 Dr. Ö̆̆gr. Üyesi, Boğaziçi Üniversitesi, Fen Edebiyat Fakültesi Çeviribilim Bölümü (İstanbul, Türkiye), sule.demirkol@boun.edu.tr, oooo-0002-3557-5758 [Makale kaylt tarihi: 04.05.2020-kabul tarihi: 20.06.2020; DOI: $10.29000 /$ rumelide.752909]
\end{abstract}


translations. As also indicated by Maria Tymoczko, translators always have to select parts of the source text, emphasizing some elements while excluding some others as it is not possible to render all the content of a source text in a given target language. As a result, they provide partial representations of the source text but these partial representations metonymically stand for the whole. The present article argues that a similar selection and elimination process applies to the selected city narratives which also provide partial representations of Istanbul. The two authors conceived as translators of the city are seen to foreground different aspects of their source texts, and provide "metonymic" representations of the city, which establish a symbolic order within which the city is construed.

Keywords: Translation Studies, literary translation, Ahmet Hamdi Tanpınar, Orhan Pamuk, Istanbul in Turkish literature

\section{Giriş}

John Freely, İstanbul üzerine yazarken "iki ayağını iki farklı kıtaya basan tek şehir”2 olarak betimliyor İstanbul'u (Freely, 1998). Bu coğrafi konumu nedeniyle İstanbul, hem iki farklı kıtayı bir araya getiriyor hem de farklı geleneklerin ve kültürlerin iç içe geçtiği bir alan oluşturuyor. Şehri anlatmak için sıklıkla "köprü" metaforuna başvurulmasının nedeni de bu özel konumu olsa gerek (Eker Roditakis, 2015). Fakat, geçiş noktalarında yer almak her zaman olumlu sonuçlar doğurmaz; çünkü Michael Cronin'in de ifade etmiş olduğu gibi "köprüler birleştirdikleri kadar ayırır da" (Cronin, 2006: 123). İki kıtanın ve iki geleneğin birleştiği/ayrıştığı bir noktada yer alan İstanbul için bu durum, bir kimlik mücadelesini de beraberinde getirir. Ahmet Hamdi Tanpınar (1901-1962), Orhan Pamuk (doğumu 1952) ve Elif Şafak (doğumu 1971) gibi birçok yazar, şu ya da bu taraftan birini seçmek yerine bu gerilimle yaşamayı ve bu mücadeleyi edebi çalışmalarının merkezine yerleştirmeyi yeğlemiştir. Orhan Pamuk, kendisi üzerinde büyük etkisi olduğunu belirttiği Yahya Kemal, Reşat Ekrem Koçu, Abdülhak Şinasi Hisar ve Ahmet Hamdi Tanpınar'dan söz ederken, bu “dört hüzünlü yalnız yazar"ın "geçmişle günümüz ya da Batılıların sevdiği deyişle Doğu ile Batı arasındaki karmaşık ve yaratıcı tutumları”nın kendisini içinde yaşadığı şehrin "ruhuna hazırladığını" belirtir (Pamuk, 2007: 108).

Fakat İstanbul gibi bir şehri, tek bir anlatıya sığdırmak mümkün değildir. İstanbul hem tarih içinde hem de günümüzde çok farklı anlatılara konu olmuş ve her seferinde farklı bir çerçeve içine girmiştir. Zaman içinde değişen isimleri gibi, edebiyattaki temsilleri de farklılık gösterir. Mimarlık tarihçisi Uğur Tanyeli, şehrin farklı isimlerinden söz ederken, değişen isimleriyle birlikte şehrin de değiştiğini vurgular ve isim değişikliğinin "bir ad değişikliğinden fazlasını" ifade ettiğini belirtir (Tanyeli, 2008: 175). İsim değişiklikleri, şehrin yaşadığı toplumsal ve kültürel dönüşümlere işaret ettiği, politik ve tarihsel bağlamları hatırlattı̆̆ için özel bir dikkati gerektiriyor. Şehirler ve çeviri üzerine çok kapsamlı çalışmaları bulunan Sherry Simon da, tıpkı Tanyeli gibi, isimlerin "sarsıcı şekilde değişen gerçekliklere işaret eden hassas şifreler” olduğunu belirtiyor (Simon, 2012: 15). İstanbul'un değişen isimleri de şehrin çok katmanlı tarihini hatırlatır, çokdilli, çokkültürlü ve çoketniliyi yapısını çağrıştırır. Böyle çok katmanlı bir yapıya sahip olan İstanbul, şehir üzerine yazan farklı yazarların yapıtlarında da çok çeşitli şekillerde çıkar karşımıza. Bu yazarlar, şehrin tarihinden ya da bugününden farklı bir katmana odaklanıp, şehrin farklı bir yönünü öne çıkarır. Bu makalede gösterilmeye çalışılacağı gibi, şehir üzerine yazan yazarların bu yaptıkları, bir çevirmenin çevirdiği kaynak metinle ilişkisine benzetilebilir. Tıpkı tamamen aktarılması mümkün olmayan bir kaynak metni başka bir dile aktarması gereken bir çevirmenin bazı tercihler yapması ve metnin bazı özelliklerini öne çıkarırken bazılarından vazgeçmesi

2 Bibliyografyada çevirmeni belirtilmeyen tüm alıntılar, makale yazarı tarafından çevrilmiştir. 
gibi, şehir üzerine yazan yazarlar da şehrin bütün özelliklerini bir metne aktaramayacakları için tercihler yapmak durumda kalır. Bu nedenle ürettikleri şehir anlatıları kısmi, taraflı ve metonimiktir. İlerleyen sayfalarda, edebiyat ve çeviribilim alanlarında yapılan güncel kuramsal tartışmalardan yararlanarak, Türkçede İstanbul üzerine yazllan edebi metinleri, şehrin birer çevirisi olarak incelemek için bir yaklaşım önerilecektir. Vaka çalışması olarak Ahmet Hamdi Tanpınar’ın “İstanbul” başlıklı denemesi ve Orhan Pamuk'un İstanbul, Hatıralar ve Şehir başlıklı kitabı incelecektir. Bu yaklaşım doğrultusunda, Tanpınar ve Pamuk, şehri bir kaynak metin olarak okuyan ve bu metni Türkçeye aktaran çevirmenler olarak ele alınacaktır. Bu yaklaşımın, Türk edebiyatındaki şehir anlatılarını incelemek için yeni bir perspektif sunması amaçlanmaktadır.

\section{Metin olarak şehir}

Bu makale kapsamında, Orhan Pamuk ve Ahmet Hamdi Tanpınar'ın İstanbul üzerine yazdıkları metinler, şehrin birer "çevirisi" olarak incelenirken Pamuk ve Tanpınar da şehrin "çevirmenleri” olarak ele alınmaktadır. Bu yaklaşım, öncelikle şehrin bir "söylem" (Barthes, 1985) olarak çözümlenebileceği ve "kültürel bir metin" (Wirth-Nesher, 1996: 9) olarak okunabileceği görüşüne dayanmaktadır. Başka bir deyişle, "çeviri" ve "çevirmen" kavramları sadece bir metafor olarak kullanılmamaktadır. Pamuk ve Tanpınar’ın, şehir üzerine yazan başka birçok yazar gibi, şehri bir kaynak metin olarak okudukları ve okudukları bu metni doğal bir dil olan Türkçeye çevirdikleri görüşü ileri sürülmektedir.

Şehrin bir "söylem” ya da bir "metin” olarak kavramsallaştırılabileceği görüşü, sosyal bilimler alanında yeni bir görüş değildir. Roland Barthes, Türkçeye Çağdaş Söylenler başlı̆̆ı altında Tahsin Yücel tarafından çevrilmiş olan 1957 tarihli Mythologies başlıklı kitabında, kitle kültürünü bir "söylem" olarak ele almış ve bu söylemi hem göstergebilimsel açıdan incelemiş hem de ideolojik açıdan eleştirmiştir. 1967 yılında yazdığı "Sémiologie et urbanisme" ("Göstergebilim ve Şehircilik") başlıklı makalede ise şehrin göstergebilimsel açıdan incelenmesine yönelmiş ve şehrin de bir "söylem" olarak ele alınabileceğini belirtmiştir (1985). Barthes, bu makalesinde "şehrin dilinden" söz ederken bu kavramı bir metafor olarak kullanmamış, göstergebilimden yararlanarak bu dili somut hale getirmenin mümkün olabileceğini belirtmiştir. Barthes, söz konusu makalede açık bir yöntem ve vaka incelemesi sunmamış olsa da bu dili anlamak için şehre bir "okur" gibi yaklaşarak "şehri okumanın" yararlı olacağını vurgulamıştır. Şehirle farklı ilişkiler kurmuş olan çeşitli okurların şehri nasıl okuduklarını inceleyerek şehrin dilini kavrayabileceğimizi belirtmiştir. Ancak yine Barthes'ın da belirtmiş olduğu gibi elimizde bu tür okumalardan çok fazla bulunmamaktadır ve şehir üzerine yazan edebiyatçlların sundukları metinler, şehrin dilini anlamak için başvurulabilecek başlıca kaynaktır (Barthes, 1985).

Çeviribilim alanında ise kültürü bir "metin" olarak ele alma yaklaşımı Michaela Wolf'un çalışmalarında karşımıza çıkar. Wolf, Clifford Geetz'in incelemelerinden yararlanarak kültürü "montajlanmış metinler" olarak kavramsallaştırır ve çevirmenin üstlendiği iş ile etnografın üstlendiği iş arasında bir kıyaslama yapar. Hem çevirmenin hem de etnografın, diğer kültürün "ilk okurları" olduklarını belirtir (Wolf, 1995: 128).

Şehir üzerine yazılan anlatıları şehrin çevirisi olarak okuma yaklaşımı, Roman Jakobson'un çeviriyle ilgili üçlü ayrımını çağrıştırabilir (Jakobson, 2004). Jakobson, "Çevirinin Dilbilimsel Özellikleri Üzerine" başlıklı makalesinde çeviriyi üç farklı kategori altında ele alır ve "diliçi”, "dillerarası" ve "göstergelerarası" çeviri kavramlarını ortaya atar. Bu bağlamda, göstergelerarası çeviri için "dilsel göstergelerin dilsel olmayan gösterge dizgeleri aracılığıla yorumlanması" tanımını getirir (Jakobson, 2004: 90). Jakobson bu makalesinde dilsel göstergelerle dilsel olmayan göstergeler arasındaki 
aktarımdan söz ediyor olsa da önceliği dilsel öğelere verir ve dilsel öğelerin dilsel olmayan öğelere çevirisinden söz eder. Tam tersinden, yani dilsel olmayan göstergelerin dilsel göstergelere aktarımından ise söz etmez. Bu makalede, yine farklı gösterge dizgeleri arasındaki bir aktarımdan söz ediliyor olsa da Jakobson'un tanımındakinden farklı olarak, dilsel olmayan göstergelerin dilsel göstergelere aktarımına odaklanılmaktadır.

Bu makalede, Barthes'ın görüşlerinden yola çıkarak ve bir adım daha ileri giderek, şehri "okuyan" edebiyatçların şehir üzerine ürettikleri metinleri şehrin bir "çevirisi” olarak ele alabileceğimiz görüşü savunulmakta, bu bakış açısıyla, Ahmet Hamdi Tanpınar ve Orhan Pamuk, İstanbul'un çevirmenleri olarak ele alınmaktadır. Aynı yaklaşımla, bu yazarların İstanbul üzerine yazdıkları metinler de İstanbul'un farklı çevirileri olarak kabul edilmektedir. Barthes, hepimizin şehri bir "okur" gibi okuyabileceğimizi vurgular ve şehrin dilini kavramak için edebiyatçların sundukları "okumalara" bakmamızı önerir, ancak bu "okumalar" aynı zamanda birer "yazıdır" ve yazarların şehri okuyarak ürettikleri bu "yazılar" şehrin birer "çevirisi” olarak ele alınabilir. Bu yazıları çeviri olarak ele alma yaklaşımı, aynı şehrin farklı yazarların metinlerinde çok farklı şekillerde betimlenmesini tartışmak için önemli araçlar sunabilir. Çeviribilim alanında çevirinin "metonimik" yönleri üzerine yapılan tartışmalar (Tymoczko, 1999; 2000), çevirmenlerin "bilişsel durumları" (Boase-Beier, 2003) ve "tavırlarının" (Hermans, 2007) çeviri sürecini nasıl yönlendirdiği konusundaki sorular, şehir anlatılarını yeni bir gözle okumaya yardımcı olabilir.

\section{3. Şehir anlatılarının ve çevirinin metonimik yönleri}

Daha önce de belirtilmiş olduğu gibi bu makale kapsamında Orhan Pamuk'un ve Ahmet Hamdi Tanpınar'ın İstanbul üzerine yazmış oldukları metinler, şehrin çevirisi olarak ele alınmakta ve şehir, bu çevirilerin kaynak metni olarak görülmektedir. Böyle bir çerçeveden bakıldığı zaman, farklı yazarların (örneğin Tanpınar'ın ve Pamuk'un) ürettikleri şehir anlatılarının arasındaki farklar, herhangi bir metnin farklı çevirmenler tarafından yapılan çevirilerinin arasındaki farklara benzetilebilir ve bu farklılıklar, çevirinin "kısmiliği” ve "metonimik" yönüyle açıllanabilir (Tymoczko, 1999; 2000). Çeviride kaynak metnin tüm özelliklerini aktarmanın mümkün olmadığını belirten Maria Tymoczko, bu durumu şu şekilde açıllar:

"Bir kaynak metinde bulunan bilgi ve anlam, her zaman için, bir çevirinin aktarabileceğinden çok
daha kapsamlıdır. [...] Bunun bir sonucu olarak çevirmenler bazı tercihlerde bulunmak, metnin bazı
yönlerini ya da kısımlarını aktarmak ve öne çıkarmak zorundadırlar. Bu tercihler ise, kaynak
metinlerinin temsillerinin oluşmasına yardım eder, ancak bu temsiller kısmidir, taraflıdır"
(Tymoczko, 2000: 2).

Çevirmenlerin yaptıkları tercihler sonucunda kaynak metnin bazı özellikleri çeviriye aktarılırken bazı özellikleri dışarıda bırakılır. Bu nedenle çeviri hem kısmi hem de "metonimiktir" (Tymoczko, 1999: 57). Tymoczko, çevirinin metonimik özelliğini tartışırken, çevirinin "bütünlerin yerine geçecek parçalar, görünümler ve özellikler seçip çıkararak, bir kaynak metni, bir edebiyat geleneğini, bir kültürü ve bir halkı, alıcı okur kitlesinin gözünde, metonimik olarak inşa" ettiğini belirtir ve bu metonimik temsilin sonucunda toplumları ve halkları anlamak için kullanılan "simgesel bir düzen" kurulduğunu ekler (Tymoczko, 1999: 57).

Tymoczko'nun çeviri hakkındaki bu görüşleri şehir anlatılarına ve daha özelde İstanbul anlatılarına uyarlanabilir. İstanbul'un tüm özelliklerini tek bir metne aktarmak mümkün olamayacaktır, zaten şehir üzerine yazan yazarlar da şehrin sadece bazı özelliklerini öne çıkarmayı, bazı yönlerini vurgulamayı ve bazılarını dışarıda bırakmayı tercih eder. Örneğin şehrin tarihinden sadece belirli bir döneme odaklanır 
ya da şehrin sosyal katmanlarından sadece biri üzerinde durur. Benzer bir şekilde şehrin sadece bazı semtlerinden söz edip diğerlerini dışarıda bırakmayı da seçebilir. Şehir üzerine yazan yazarlar, bu seçme ve eleme süreci sonunda kısmi bir anlatı üretir, ancak ürettikleri anlatı okura ulaştığı zaman metonimik olarak tüm şehrin yerine geçer ve tüm şehri temsil eder. Böylece tüm şehri anlamakta kullanılacak "sembolik bir düzen" kurmuş olur.

$\mathrm{Bu}$ şekilde üretilen şehir anlatıları bir dilden başka bir dile çevrilirken bir seçme ve eleme süreci daha başlar. Bu aşamada şehir anlatısı, dillerarası çeviri yapan çevirmenlerin tercihleri ve kararları doğrultusunda yeniden şekillenir. Her iki aşamada da çevirmenlerin kararları, bu çevirmenlerin "bilişsel durumlarını" ve "tavırlarını" ortaya koyar.

\section{4. Şehir anlatılarında çevirmenin izi: Çevirmenin "tavrı" ve "bilişsel durumu"}

Edebi bir anlatıda karşımıza çıkan şehir, çoğunlukla içinde gezdiğimiz şehirden farklıdır. Ahmet Hamdi Tanpınar'ın ya da Orhan Pamuk'un anlattığı İstanbul, şehirde yaşayanların ya da şehri ziyaret edenlerin gördüklerinden, deneyimlediklerinden çok farklı olabilir. Bu nedenle şehir anlatıları üzerinde çalışırken "gerçek" şehirle "anlatıdaki" şehir arasındaki ayrıma dikkat çekmek yerinde olur. Virginia Woolf da bu konu üzerine yazarken "bir yazarın yurdu kendi beyninde yer alan bir topraktır; bu hayali şehirleri elle tutulur taşa ve duvara dönüştürmek istersek hayal kırıklığına uğrayabiliriz” (Woolftan alıntılayan Chapman Sharpe, 1990: xi) yorumunda bulunmuştur. Chapman Sharpe da edebi anlatılardaki şehirlerle gerçek şehirler arasındaki farkı benzer bir şekilde vurgulamıştır:

"Edebi metinleri inceleyerek Baudelaire'in Paris'ini, Blake'in, Wordsworth'ün ya da Eliot'ın Londra'sını anlıyormuş gibi yapamayız. Fakat okumalarımız sayesinde, bu şehirlerde yaşayan şairlerin şehri nasıl algıladığını, ve bu algının edebiyattaki temsilinin şehir hakkında daha önceden yazılan metinlerin etkisiyle nasıl şekillendiğini kavrayabiliriz” (Chapman Sharpe, 1990: xi).

Şehir anlatılarını okuyarak, bunları üreten yazarların dünyasına ve imgelemine yaklaşabiliriz, fakat "gerçek" şehir hakkında ancak kısmi ve taraflı bir bilgiye ulaşırız. Bu görüş, bu makale kapsamında ortaya atılan, şehir anlatılarını şehrin bir çevirisi olarak okuma yaklaşımıyla uyum içindedir çünkü her çeviri gibi şehrin çevirisi de çevirmenden izler taşır.

Çeviride biçem üzerine kapsamlı çalışmaları bulunan çeviribilimci Jean Boase-Beier, biçemin oluşmasında yazarın ve çevirmenin verdiği kararların önemini hatırlatır ve bu kararların metni üreten kişinin "bilişsel durumuyla" bağlantısına dikkat çeker (Boase-Beier, 2003: 253). Boase-Beier, "bilişsel durum" ("cognitive state") kavramının, "dile ve biçeme ilişkin formlar ve kısıtlamalar, edebiyata dair uzlaşımlar, kültürel arka plan ve hedef kitle gibi konularda sahip olunan bilgileri” içerdiğini belirtir ve tüm bu faktörlerin karşıllklı bir etkileşim içinde olduğunu ekler (Boase-Beier, 2003: 253). "Bilişsel durum", "dünya görüşü” kavramıyla benzerlik gösteriyor olsa da daha kapsamlı bir tanımı vardır. BoaseBeier'e göre "dünya görüşü”, "inançları ve kültürel varsayımları" ifade eder fakat "bilişsel durum" kavramının içine giren ve yukarıdaki tanımda sözü edilen bilgi türlerini kapsamaz. Boase-Beier, karar verme sürecinde "bilişsel durum" kadar "dünya görüşünün" de önemli bir rolü olduğunu da kabul eder (Boase-Beier, 2003: 253-254). Yaptığı vaka incelemelerinde bir çeviri metinde kaynak metnin yazarından izler bulunduğu kadar çevirmenden de izler bulunduğunu vurgular ve çevirmen kararlarının şekillenmesinde, çevirmenin dünya görüşünün, profesyonel ve kültürel altyapısının, metni okuması beklenen okur kitlesinin ve pazarlamaya ilişkin stratejilerin önemli rolü olduğunu belirtir (Boase-Beier, 2003). 
Theo Hermans da çevirmenin çevirideki izlerinin peşine düşmüştür ve her çeviride çevirmenin izlerinin bulunabileceğini ileri sürer (Hermans, 2007). Hermans’a göre "bir çeviri, çeviri olarak durduğu sürece, bir çevirmenin varlığını ve dolayısıyla da bir çevirmenin özne olarak duruşunu barındırır içine kazılı şekilde, ne denli gizlenmiş olsa bile" (Hermans, 2007: 27). Özellikle çevirmenlerin ideolojik ya da ahlaki açıdan karşı çıktıkları görüşleri savunan metinleri çevirmek durumunda oldukları örneklere odaklanan araştırmacı, bu gibi durumlarda çevirmenlerin çevirdikleri metinde savunulan görüşlerle ilgili eleştirilerini her koşulda metne yansıttıklarını, kaynak metni sözcüğü sözcüğüne aktarmaya yöneldikleri durumlarda bile çeviride eleştirel bir iz bıraktıklarını belirtir (Hermans, 2007: 65). Hermans, buradan yola çıkarak çeviride birden fazla sesin bulunduğunu ve çeviri metinlerdeki sözcüklerin görünenden fazlasını söylediklerini ileri sürer; çevirmenlerin aynı anda hem kaynak metnin yazarı adına konuştuğunu hem de çekincelerini ortaya koyduğunu iddia eder (Hermans, 2007: 65). Araştırmacı bu bağlamda çevirmenin kaynak metne belirli bir "tavırla" yaklaştı̆̆ını ve bu tavrın, çeviri üzerinde belirleyici bir etkiye sahip olduğunu belirtir (Hermans, 2007: 83). Hermans, özellikle çevirmenlerin, çevirdikleri metinlerde ifade edilen görüşlere karşı tavır aldıkları durumlar üzerine eğilmiş olsa da çevirmen tavrının her çeviride belirleyici olduğu sonucuna ulaşır (Hermans, 2007: 84-85).

Bu iki araştırmacının görüşleri bir arada değerlendirildiğinde, Theo Hermans'ın gözlemlediği çevirmen "tavrının”, Jean Boase-Beier'in üzerinde durduğu "bilişsel durumun” bir sonucu olduğu söylenebilir.

\section{5. İstanbul'un iki çevirmeni: Ahmet Hamdi Tanpınar ve Orhan Pamuk}

Makalenin bundan sonraki kısımlarında, Ahmet Hamdi Tanpınar'ın 1945 tarihli “İstanbul” denemesi (Tanpınar, 2006) ve Orhan Pamuk'un 2003 tarihli İstanbul, Hatıralar ve Şehir başlıklı kitabı (Pamuk 2007), yukarıda açıklanan kuramsal çerçeve doğrultusunda, İstanbul'un iki farklı çevirisi olarak incelenecektir. Aynı bakış açısıyla, Tanpınar ve Pamuk, şehrin iki çevirmeni olarak ele alınacaktır. Bu iki yazarın sunmuş olduğu İstanbul çevirilerinin kısmi ve taraflı yönleri araştırılacak, bu çevirilerin metonimik özelliği sorgulanacaktır. Ayrıca Tanpınar'ın ve Pamuk'un, şehrin çevirmenleri olarak sergiledikleri "tavrın" ve "bilişsel durumlarının" metni nasıl şekillendirdiği anlaşılmaya çalışlacaktır3.

Vaka çalışması olarak bu iki metnin seçilmesinin çeşitli nedenleri var. Öncelikle Tanpınar, Osmanlı Devleti'nin yıkılması ve Türkiye Cumhuriyeti'nin kurulması sürecinde ve bundan da önce başlayan "Batılılaşma” -ya da Tanpınar’ın deyişiyle "medeniyet değiştirmesi” (Tanpınar, 1996)- kapsamında şehrin yaşadığı değişimi yakından izlemiş ve tüm edebiyatında şehre önemli bir yer ayırmış bir yazardır. İstanbul'un kültürel, edebi, müzikal ve mimari geleneklerine özel bir ilgi duyan Tanpınar, şehrin işgalini görmüş bir aydın olarak, bu geleneklerin tamamen yitirilmesi korkusunu da yaşamıştır. Şehre bakarken geçmişi ve geleceği birlikte düşünür. Ayrıca şehri yazarken kullandığı biçem de özel olarak dikkat çekicidir. Pamuk da Tanpınar gibi İstanbul'u edebiyatının merkezine yerleştirmiş ve Tanpınar'dan çok etkilendiğini belirten bir yazardır. Bununla birlikte Pamuk, Tanpınar'ın yazılarında söz ettiği geleceğin içinde yaşadığı için şehre ve Tanpınar'ın yazılarına farklı bir perspektiften bakar. Tanpınar, şehrin içinde bulunduğu "medeniyet değişimini” içinden gözlemlerken şehrin gelecekte nasıl olacağını kendi konumundan bakarak sorgulamıştır. Tanpınar'dan yaklaşık yarım asır sonra doğan Pamuk ise Tanpınar'ın yaşadığı dönemde şehrin maruz kaldığı dönüşüme farklı bir zaman diliminden ve farklı bir konumdan bakmaktadır. Ayrıca Pamuk, 2006 yılında Nobel Edebiyat Ödülü’nü almış olduğu için uluslararası edebiyat dünyasında çok iyi tanınan ve yapıtları pek çok dile çevrilen bir yazardır. Bu

3 Ahmet Hamdi Tanpınar'ın ve Orhan Pamuk'un İstanbul'la olan ilişkisini ve yapıtlarında şehrin temsilini kapsamlı bir şekilde incelemek bu makale kapsamında mümkün olamayacaktır. Burada, sadece incelenen metinlerde öne çıkan sınırlı sayıda örnek üzerinde durulacaktır. Daha kapsamlı incelemeler için, yazarın bu makaleye kaynaklık eden doktora tezi bir kaynak olabilir. Bkz. Demirkol Ertürk 2010. Ayrica bkz. Demirkol Ertürk 2011, 2012, 2013a, 2013b. 
ayrıcalıklı konumu nedeniyle, hem İstanbul hem de Tanpınar hakkında yazdıkları, şehrin ve Tanpınar’ın yapıtlarının uluslararası düzeyde alımlanması açısından belirleyici olmaktadır. Bu nedenle, Tanpınar'ın ve Pamuk'un İstanbul üzerine yazdıkları metinlerin yan yana incelemesi sonucunda dikkat çekici verilere ulaşlabilir ve her iki yazarı/çevirmenin tavırlarının ve bilişsel durumlarının şehir anlatısını/çeviriyi nasıl biçimlendirdiği yakından araştırılabilir.

\section{Tanpınar'ın İstanbul çevirisi}

Ahmet Hamdi Tanpınar'ın İstanbul'a yaklaşımını kavramak ve şehrin çevirmeni olarak "tavrını" belirli bir bağlam içinde gözlemleyebilmek için, yazarın ilk olarak 1951 yılında yayımlanmış olan "Medeniyet Değiştirme ve İç İnsan" (Tanpınar, 1996) başlıklı yazısı yol gösterici olabilir. Tanpınar, uzun bir geçmişi olan ve Tanzimat'la ve Cumhuriyet’in ilanıyla hız kazanan Batılılaşma sürecini ele alırken, bu değişimi yaşayan insanların iç dünyalarına dikkat eder ve kısa sürede gerçekleşen bu köklü değişim sonucunda oluşan "zihniyet ve iç insan buhranına" odaklanır (Tanpınar, 1996: 34). Bu çerçevede, "Batı" ve "Doğu" medeniyetleri arasında kalan Türk halkının yaşadığı "ikiliğe" dikkat çeker ve şöyle der: "Bu ikilik, evvela umumî hayatta başlamış, sonra cemiyetimizi zihniyet itibariyle ikiye ayırmış, nihayet ameliyesini derinleştirerek ve değiştirerek ferd olarak da içimize yerleşmiştir" (Tanpınar, 1996: 34). Tanpınar, bu değişimle beraber "devam ve bütünlük fikrinin" kaybedildiğini ve bu nedenle bir "kıymet buhranı" yaşandığını vurgular: "Bizi değiştirecek şeylere karşı ne bir mukavemet gösterebiliyoruz, ne de ona tamamiyle teslim olabiliyoruz. Sanki varlık ve tarih cevherimizi kaybetmişiz; bir kıymet buhranı içindeyiz” (Tanpınar, 1996: 35).

"Medeniyet değişimi” ve "kıymet buhranı” meseleleri, Tanpınar’ın tüm yapıtlarında kendini gösterir, ancak Tanpınar’ın yapıtları sadece içerikleriyle değil biçem özellikleri nedeniyle de dikkat çeker. Berna Moran'ın da belirtmiş olduğu gibi Tanpınar'da biçem ve içerik birbirini tamamlamaktadır (Moran, 1998). Fethi Naci ve Berna Moran, Tanpınar'ın Huzur başlıklı romanı üzerinde kaleme aldıkları incelemelerde Tanpınar'ın biçem konusunda kimi zaman aşırıya kaçtığını belirtmiş olsa da (Naci, 2008: 185; Moran, 1998: 212) her ikisi de Tanpınar’ın anlatımının şiirsel yönünü vurgular ve yapıtın "sanatsal gücüne” (Naci, 2008: 185) dikkat çeker. Berna Moran, "Tanpınar’ın dünyaya ve yaşama belli bir kültür düzeyinden, ince bir zevk ve duyarlıkla” baktığına dikkat çeker (Moran, 1998: 223).

Tanpınar'ın "bilişsel durumunu" belirleyen bu özellikler, yazarın İstanbul anlatısında da öne çıkar ve şehrin çevirisini belirler. Tanpınar'ın "İstanbul” denemesinde kullandığı biçemde metaforlar ve şiirli bir dil öne çıkar. Tanpınar aynı metinde İstanbul'u bir "şiir dünyası" olarak betimlediği için (Tanpınar, 2006: 122), bu biçemin anlatıyla son derece uyumlu olduğu söylenebilir. Şiirli bir dil kullanarak İstanbul'u bir şiir dünyası olarak resmeden Tanpınar'a göre her İstanbullu da az çok şairdir (Tanpınar, 2006: 121). Öte yandan, Tanpınar'ın İstanbul'u anlatırken İstanbullunun iç dünyasına yönelmesi de dikkat çekidir. Yazarın "İstanbul” başlıklı denemesinin burada incelenen ilk bölümünde Tanpınar, İstanbulluların iç dünyasını öne çıkarır, onların hayallerini ve hülyalarını anlatmaya özen gösterir. İstanbul'un, insanların hayal gücünü nasıl harekete geçirdiğini anlatır. Bu bölümde "insanın içi", "muhayyile", "hayal” ve "hülya" sözcüklerinin sıcça tekrarlandığı görülür.

Tanpınar'ın İstanbul'unda egemen olan ruh halini ise, yine sıkça tekrarlanan "hasret”, "özlemek" ve "daüssıla" duyguları ifade eder. Sadece burada incelenen giriş bölümünde, "hasret" sözcüğü dört kere kullanılmıştır; "özlemek” ve "özleyiş” sözleriyle beraber "daüssıla” sözcüğü de üç kere geçmektedir. Tanpınar, İstanbul'un kendi neslinde uyandırdı̆̆ı duygudan söz ederken de "İstanbul'un bugün bizde yaşayan asıl çehresini bu dâüssıla verir, diyebiliriz” (Tanpınar, 2006: 119) diye yazar. Ancak Tanpınar 
için bu “özlem" ve "hasret” duyguları olumlu anlam taşımaktadır. "Hasret”, "aydınlık" bir duygudur (Tanpınar, 2006: 119); beraberinde gelen "hüzün” ise "besleyicidir" (Tanpınar, 2006: 121). Bu noktada, Tanpınar'ın "hüzün” duygusuyla ilgili bu tavrının, Pamuk’un aynı duyguya yaklaşımından oldukça farklı olduğunu vurgulamak gerekir. Pamuk da Tanpınar'dan yola çıkarak şehri hüzünlü bir yer olarak betimler. Ancak Pamuk’ta hüzün duygusuna eşlik eden kavramlar farklıdır. Bir sonraki bölümde de gösterileceği gibi şehri siyah-beyaz, yıkık dökük bir mekân olarak betimleyen Pamuk, hüzün duygusunu kayıpla birleştirir ve İstanbul'un hüznünü “yıkıntıların hüznü” olarak adlandırır (Pamuk, 2007: 236).

Tanpınar'ın şehrin çevirmeni olarak tavrını ve şehrin hangi kısımlarını seçip öne çlkarttı̆̆ı gösteren başka bir örnek, İstanbul'un semtleri arasında yaptı̆̆ı ayrımdır. Tanpınar Beyazıt, Beylerbeyi ve Üsküdar gibi semtleri överken Beyoğlu ve Tarabya gibi semtlerden olumsuz bir şekilde söz eder. Tanpınar'a göre "Beyoğlu, hamlesi yarı yolda kalmış Paris taklidiyle hayatımızın yoksulluğunu hatırlatır", buna karşın "İstanbul, Üsküdar semtleri kendisine yetebilen bir değerler dünyasının son miraslarıyla, biz farkında olmadan içimizde bir ruh bütünlüğü kurar, hulyalarımız, isteklerimiz değişir” (Tanpınar, 2006: 120-121). Benzer bir karşılaştırma da şu şekildedir:

\begin{abstract}
"Bayezit veya Beylerbeyi Cami'inin duvarlarına yaslanarak düşünülen şeylerle, Tarabya'nın içimizdeki bir tarafa hâlâ yabancı rıhtımında, akşamın bir ten cümbüşünü andıran ışıkları içinde düşünülecek şeyler elbette birbirine benzemez. Birincilerinde her şey içimize doğru kayar ve besleyici bir hüzün hâlinde bizde külçelenir. İkincisinde bu köklü hasretten mahrum kalırız” (Tanpınar, 2006: 121).
\end{abstract}

Tanpınar’n, insanın iç dünyasına yönelen ve hüzünden olumlu bir duygu olarak söz eden yaklaşımı bu alıntıda da kendini hissettirir. Yazara göre Tarabya "içimizdeki bir tarafa hâlâ yabancı"dır ama Beyazıt ve Beylerbeyi muhitlerinde "her şey içimize doğru kayar" ve "besleyici bir hüzün” doğurur (Tanpınar, 2006: 121).

Bu örnekler bir arada düşünüldüğü zaman, Tanpınar'ı İstanbul'u bir şiir dünyası olarak betimlediği, bazı semtleri överken diğerlerinden daha olumsuz söz ettiği ve metninin geri kalan kısımlarında da özellikle bu övülen semtlere odaklandığı görülür. Ayrıca Tanpınar'ın insanların iç dünyasına odaklanarak şehri bir hayaller ve hülyalar şehri olarak betimlediği anlaşlır. "Hüzün" ve "hasret" duyguları, bu anlatıda öne çıkan duygulardır ancak bunlar "besleyici" ya da "aydınlı" yönleriyle anılmakta, olumsuz duygular olarak görülmemektedir. $\mathrm{Bu}$ şekilde kurulan İstanbul anlatısının/çevirisinin, yazarın/çevirmenin edebi biçemiyle beraber bilişsel durumunu ve medeniyet değişimi konusuyla ilgili tavrını yansıttı̆̆ görülmektedir.

\title{
7. Pamuk’un İstanbul çevirisi
}

Önceki bölümlerde de ifade edilmiş olduğu gibi Orhan Pamuk, Ahmet Hamdi Tanpınar'ın yapıtlarından ve İstanbul'a yaklaşımından çok etkilenmiştir. Bununla birlikte bu iki yazarın şehre bakışları farklıdır. Tanpınar, şehrin “eski” ve "yeni” arasındaki mücadelesini ve değişim sürecini yaşayarak gözlemlemiş, şehrin geçmişine bakarak geleceğini hayal etmiştir. Pamuk ise Tanpınar’ın zihninde canlandırdığı gelecekten geçmişe doğru bakar. Tanpınar'ın övgüyle söz ettiği eski İstanbul semtlerinde değil, Batı modelinde kurulan semtlerde büyümüştür. Pamuk, şehre bakışını anlatırken, eski İstanbul semtlerinden kaçıp "Pera'nın arkalarında” yeni bir medeniyet kurmak üzere yola çıkan "modernleşmeci hareket”in bir çocuğu olarak tanımlıyor kendisini. Bu hareketin artık tarihe yöneldiğini, eskiye bakarak bir zamanlar ardında bıraktıklarını geri almak istediğini belirtiyor. Kendi bakışını da bir "geriye bakış" olarak nitelendiriyor (Pamuk, 1999: 61). 
Istanbul and its translators: Translation of the city in Ahmet Hamdi Tanpınar's and Orhan Pamuk's literary narratives / Ş. Demirkol Ertürk (pp. 876-886)

Pamuk, Pera'nın arkalarından şehre bakarken şehrin tarihiyle de ilgilenir. İstanbul, Hattralar ve Şehir kitabında, yakın tarihte yaşanan süreçler özellikle önemli bir yer tutar. Pamuk, bu tarihe biraz daha uzak bir mesafeden baktığı için daha eleştirel bir yaklaşım sergileyebilmektedir. Osmanlı döneminde ve cumhuriyetten sonra girişilen "modernleşme" ya da "Batılılaşma" çabalarını eleştiren Pamuk, yeni Türk ulusunu şekillendirmek amacıyla "Avrupalı" ve "Batılı” değerlerin öne çıkarılmasının başarısızlıkla sonuçlandığını belirtir ve bu sürecin ancak bir kimlik kaybıyla sonuçlandığını ileri sürer:

\begin{abstract}
"Batılılașma çabası, modernleșme isteğinden çok yıkılan imparatorluktan kalan keder verici, acıklı hatıralarla yüklü eşyalardan kurtulma telaşı gibi gelmiştir bana: Tıpkı birden ölüveren güzel bir sevgilinin yıkıcı anısından kurtulmak için elbiselerinin, takılarının, eşya ve fotoğraflarının telaşla atılması gibi. Yerine güçlü, kuvvetli, yeni bir şey, Batılı ya da yerli, modern bir dünya kurulamadığ için bütün bu çaba daha çok geçmişi unutmaya yaradı; konakların yakılıp yıkılmasına, kültürün basitleştirilip güdükleştirilmesine, ev içlerinin yaşanmamış bir kültürün müzesi gibi düzenlenmesine yol açtı" (Pamuk, 2007: 34).
\end{abstract}

Pamuk'a göre "Batılılaşma” girişimi sadece kendi içinde başarısızlığa uğramakla kalmamış, beraberinde gelen milliyetçi hareketler sonucunda şehrin çokkültürlü yapısının da yok olmasına neden olmuştur. Pamuk, İstanbul'u yazarken, şehrin eski çokkültürlü, çokdilli ve birçok farklı etnik unsuru bir arada barındıran yapısının kaybolmuş olduğunu sık sık dile getirir. Bu değişim, Pamuk'a göre İstanbul'u "siyah beyaz" bir şehre dönüştürmüştür: "Osmanlı İmparatorluğu yıkılıp gidince ve Türkiye Cumhuriyeti ne olduğuna karar veremediği kendi Türklüğünden başka bir şey görmeyip dünyadan kopunca İstanbul eski çok dilli, muzaffer ve tantanalı günlerini" kaybetmiş, "siyah-beyaz ve tek sesli, tek dilli bir yere" dönüşmüştür (Pamuk, 2007: 223).

Tüm bu kayıplarla beraber, Pamuk'un şehre bakışında öne çıkan duygu "hüzün"dür. Ancak Pamuk'taki "hüzün”, Tanpınar'dakinden farklıdır ve yukarıdaki alıntıda da görüldüğü gibi bir kayıp duygusundan kaynaklanmaktadır. Pamuk'un gözünde İstanbul, geçen zaman içinde "fakirleşmiş, dünyadaki gücünü ve çekimini kaybettiği için işsiz ve ücra bir kent” olmuştur (Pamuk, 2007: 229). Bu nedenle Pamuk, kendi çocukluğunun İstanbul'unu "büyük ve yoksul bir taşra şehri" olarak betimler (Pamuk, 2007: 229).

Pamuk'un İstanbul'la ilgili bu görüşlerini kabul edenler olacağı gibi karşı çıkanlar da olabilir. Bu özel bakış aslında Pamuk'un şehrin bir çevirmeni olarak tavrına da işaret eder. Pamuk'un İstanbul'u üzerine yazan Esra Akcan da şehrin bugün çok farklı bir görünümü olduğunu, artık Pamuk'un çocukluğunda gördüğü gibi siyah beyaz bir şehir olmadığını belirtir ve İstanbul'u çok renkli, hareketli bir metropol, sürekli gelişen ve büyüyen, hızlı ve dinamik bir şehir olarak betimler (Akcan, 2006: 42-43). Ancak Pamuk, bu renkli ve dinamik şehre değil, siyah beyaz ve hüzünlü şehre yönlendirmek ister bakışını. Bu tavır, Pamuk’un edebiyatla ilgili görüşleriyle de yakın ilişki içindedir. Pamuk, Nobel konuşmasında bu tavrı açıkça ifade eder:

\footnotetext{
"Bugün edebiyatın asıl anlatması ve araștırması gereken șey, insanoğlunun temel derdi ise, dıșarıda kalmak ve kendini önemsiz hissetme korkuları, bunlara bağlı değersizlik duyguları, bir cemaat olarak yaşanan gurur kırıklıkları, kırılganlıklar, küçümsenme endișeleri, çeşit çeşit öfkeler, alınganlıklar, bitip tükenmeyen aşağılanma hayalleri ve bunların kardeşi milli övünmeler, şişinmeler...” (Pamuk, 2006: 7).
}

Pamuk, bu alıntıdan da anlaşılacağı üzere "dışarıda kalmak ve kendini önemsiz hissetme korkuları"na, "bir cemaat olarak yaşanan gurur kırıklkları"na önem vermektedir. Yazarın edebiyatla ilgili bu yaklaşımının, şehrin bir çevirmeni olarak tavrını da belirlediği görülmektedir çünkü Pamuk, İstanbul'u yazarken de benzer duygulara odaklanır ve şehri "dünyadaki çekimini ve gücünü kaybetmiş", "ücra”, "siyah beyaz" bir yer olarak anlatırken şehrin hareketli ve renkli yüzünü anlatısının dişında tutar. Yine bu alıntıda da karşımıza çıkan milliyetçilik eleştirisi, İstanbul anlatısında da vurguludur ve İstanbul 
milliyetçi akımlar nedeniyle çokkültürlü, çokdilli yapısını kaybetmiş "monoton” bir şehir olarak betimlenir.

\section{Sonuç}

Bu makalede, edebi yapıtlarında İstanbul'u özel bir konuma yerleştirmiş olan Ahmet Hamdi Tanpınar ve Orhan Pamuk, şehrin birer çevirmeni olarak ele alınmış, Tanpınar'ın "İstanbul” başlıklı denemesi ve Pamuk'un İstanbul, Hatıralar ve Şehir başlıklı kitabı şehrin çevirileri olarak incelenmiştir. Bu incelemede, bu iki yazarın sunmuş olduğu İstanbul anlatılarının/çevirilerinin kısmi ve taraflı olduğu, ve bununla birlikte yazarı/çevirmenin bilişsel durumu ve tavrı doğrultusunda şekillendiği ortaya koyulmuştur. Tanpınar'ın İstanbul'unda yazarın "medeniyet değişimi” konusundaki görüşleri ve şiirli anlatımı kendini göstermektedir. Bu doğrultuda şehrin eski semtleriyle yeni semtleri arasında kıyaslamalar yapıldığı ve insanın iç dünyasını beslediği belirtilen semtlerin tercih edildiği anlaşılmaktadır. Ayrıca Tanpınar’ın İstanbul'unda "hüzün” ve "hasret” duygularının "besleyici" ve "aydınlık" yönleriyle öne çlktığı gözlemlenmektedir. Pamuk'un kitabında ise İstanbul, Tanpınar'ın denemesindekinden daha farklı bir şekilde betimlendiği görülmektedir. Pamuk, Tanpınar'dan etkilenmiş bir yazar olsa da sunduğu şehir anlatısı/çevirisi yazarın kendi tavrını ve bilişsel durumunu yansıtmaktadır. Pamuk, Tanpınar'ın üzerinde durduğu "medeniyet değişimi” sürecine, tarihsel olarak biraz daha uzak bir mesafeden bakmakta ve daha eleştirel bir tavır sergilemektedir. Pamuk'un İstanbul'u da Tanpınar'ınki gibi "hüzün” yüklü bir şehirdir ama Tanpınar'daki gibi "besleyici” bir hüzün değildir bu. Pamuk, özellikle milliyetçilikle ilgili eleştirisi doğrultusunda İstanbul'u eski çokdilli ve çokkültürlü yapısını kaybetmiş "siyah beyaz", "monoton" bir şehir olarak anlatır. Nobel konuşmasında da belirtmiş olduğu gibi, edebiyatın asıl görevinin insanlığın yaşadığı "dışarıda kalmak ve kendini önemsiz hissetme korkuları"nı araştırmak, bu korkularla birlikte gelen "değersizlik" duygusunu, "gurur kırıklıkları, kırılganlıklar ve küçümsenme endişeleri”ni anlatmak olduğunu düşünen yazar, İstanbul'u bir kaynak metin olarak okurken de şehre bu perspektifle yaklaşmış ve şehri "dünyadaki gücünü ve çekimini" kaybetmiş, "ücra bir kent” ya da "yoksul bir taşra şehri” olarak betimlemiştir. Şehir birçoğumuza bundan farklı görünecek olsa da bu yazarlar şehrin bu yönlerini seçip öne çıkarmayı ve diğer bazı yönlerini dışarıda bırakmayı tercih etmiştir. Bu seçme ve eleme süreci, başka bir dile yazılmış bir metni yeni bir dile aktaran dillerarası bir çevirmenin yaşadığı süreçlere benzer. Maria Tymoczko'nun belirttiği gibi, bir kaynak metindeki tüm bilgi ve anlamın çeviride aktarılması mümkün değildir. Bu nedenle çevirmenler kaynak metnin bazı yönlerini öne çıkarırken bazılarını dışarıda bırakarak kaynak metnin kısmi ve taraflı temsillerini oluştururlar; ancak bu kısmi temsiller, metonimi yoluyla tüm metni temsil eder. Bu makale kapsamında incelenen iki şehir anlatısında da benzer bir seçme ve eleme sürecinin söz konusu olduğu, şehrin çevirmeni olarak görülebilecek iki yazarın anlatılarında şehrin farklı yönleriyle öne çıktığı ve bu anlatıların metonimik olarak tüm şehrin yerine geçerek şehrin anlaşılması için sembolik bir düzen kurduğu görülmüştür.

\section{Kaynakça}

Akcan, E. (2006). The Melancholies of Istanbul. World Literature Today, 80 (6), 39-41.

Barthes, R. (1985). Sémiologie et urbanisme. L'Aventure sémiologique içinde (ss. 261-271). Paris: Editions du Seuil.

Boase-Beier, J. (2003). Mind Style Translated. Style, 37 (3), 253-265.

Cronin, M. (2006). Translation and Identity. Londra: Routledge.

Demirkol Ertürk, Ş. (2013a). Images of Istanbul in translation: A case study in Slovenia. Across Languages and Cultures, 14( 2), 199-220. 
Demirkol Ertürk, Ş. (2013b). Şehrin Sunduğu Metni Okumak: Türkçe ve Fransızca Istanbul. Istanbul Üniversitesi Çeviribilim Dergisi, 4, 1-22.

Demirkol Ertürk, Ş. (2012). Le rôle des traductions et des réécritures dans le voyage des récits sur la ville d'Istanbul. Synergies Turquie, 5, 81-93.

Demirkol Ertürk, S.. (2011). The 'Attitude' of the Translator as an Intercultural Agent and the Role She Assumes in World Literature. Translation Studies in the New Millennium, 9, 39-50.

Demirkol Ertürk, Ş. (2010). The city and its translators istanbul metonymized and refracted in the literary narratives of Ahmet Hamdi Tanpmar and Orhan Pamuk in Turkish, English and French. Yayımlanmamış doktora tezi. Boğaziçi Üniversitesi Sosyal Bilimler Enstitüsü Çeviribilim Doktora Programı.

Eker Roditakis, A. (2015). The identity metonymics of translated Turkish fiction in English. Saliha Paker, Şehnaz Tahir Gürçağlar ve John Milton (Der.), Tradition, Tension and Translation in Turkey içinde (ss. 273-296). Amsterdam: John Benjamins.

Freely, J. (1998). Istanbul: The Imperial City. Harmondsworth: Penguin Books.

Hermans, T. (2007). The Conference of the Tongues. Manchester: St. Jerome Publications.

Jakobson, R. (2004). Çevirinin Dilbilimsel Özellikleri Üstüne, (çev. Ömer. B. Albayrak). Mehmet Rifat (Der.), Çeviribilim Nedir? Başkasının Bakışı içinde (ss. 89-97). İstanbul: Dünya Yayıncılık.

Moran, B. (1998). Bir Huzursuzluğun Romanı: Huzur. Türk Romanına Eleştirel Bir Bakış içinde (ss. 203-223). İstanbul: İletişim Yayınları, 1998.

Naci, F. (2008). Huzur. Abdullah Uçman ve Handan İnci (Der.), Bir Gül Bu Karanlıklarda. Tanpınar Üzerine Yazılar içinde (ss. 177-186). İstanbul: 3 F Yayınevi.

Pamuk, O. (1999). Bir İstanbul Romancısıyım. Bir Söyleşiden Süzülenler. İstanbul Dergisi, 29, 59-79.

Pamuk, O. (2006). Babamin Bavulu. https://www.nobelprize.org/uploads/2018/o6/pamuklecture_tu.pdf, (Erişim tarihi: 1 Mart 2020).

Pamuk, O. (2007). İstanbul, Hatıralar ve Şehir (15. Basım). İstanbul: İletişim Yayınları.

Sharpe, W. C. (1990). Unreal Cities: Urban Figuration in Wordsworth, Baudelaire, Whitman, Eliot, and Williams. Baltimore: Johns Hopkins University Press.

Simon, S. (2012). Cities in translation: Intersections of Language and Memory. Londra: Routledge.

Tanpınar, A. H. (1996). Medeniyet Değiştirmesi ve İç İnsan. Yaşadiğım Gibi içinde (ss. 34-39). İstanbul: Dergâh Yayınları.

Tanpınar, A. H. (2006). İstanbul. Beş Şehir, 22. Basım içinde (ss. 117-208). İstanbul: Dergâh Yayınları.

Tanyeli, U. (2008). "İstanbullaşmak". Pelin Derviş, Bülent Tanju ve Uğur Tanyeli (Der.), İstanbullaşmak, Olgular, Sorunsallar, Metaforlar içinde (ss. 175-178). İstanbul: Garanti Galeri.

Tymoczko, M. (1999). Translation in a Postcolonial Context. Manchester: Saint Jerome Publishing.

Tymoczko, M. (200o). Translation and Political Engagement. Activism, Social Change and the Role of Translation in Geopolitical Shifts. The Translator, 6(1), 23-47.

Wirth-Nesher, H. (1996). City Codes. Reading the Modern Urban Novel. New York: Cambridge University Press.

Wolf, M. (1995). Translation as a process of power: Aspects of cultural anthropology in translation. Mary Snell-Hornby, Zuzana Jettmarová ve Klaus Kaindl (Der.), Translation as Intercultural Communication içinde (ss. 123-134). Amsterdam: John Benjamins. 